\title{
DETERMINAN KEPATUHAN MASYARAKAT TERHADAP KEBIJAKAN PEMBATASAN KEGIATAN MASYARAKAT DALAM PENCEGAHAN PENYEBARAN COVID-19
}

\author{
Chandrika Fahira Quamila*)1, Septo Pawelas Arso², Wulan Kusumastuti ${ }^{3}$ \\ 1,2,3 Peminatan Administrasi dan Kebijakan Kesehatan ; Jurusan Kesehatan Masyarakat ; \\ Fakultas Kesehatan Masyarakat ; Universitas Diponegoro \\ Jl. Prof. Soedarto, SH. ; Tembalang ; Semarang
}

\begin{abstract}
Abstrak
Semarang merupakan kota dengan jumlah kasus COVID-19 tertinggi di Jawa Tengah. Guna mencegah penyebaran COVID-19, maka diberlakukan kebijakan Pembatasan Kegiatan Masyarakat (PKM). Namun, masih terdapat banyak masyarakat yang tidak patuh terhadap kebijakan tersebut sehingga jumlah kasus COVID-19 di Kota Semarang semakin meningkat. Penelitian ini dilakukan untuk mengetahui faktor-faktor yang memiliki hubungan dengan kepatuhan masyarakat terhadap kebijakan PKM di Kota Semarang. Jenis penelitian yang digunakan adalah kuantitatif dengan desain cross-sectional. Sebanyak 140 responden didapatkan melalui metode accidental sampling. Analisis data dilakukan secara univariat dan bivariat menggunakan uji statistik non-parametrik. Hasil penelitian menunjukkan bahwa sikap $(p=0,039)$, sarana prasarana $(p=0,002)$, pengawasan $(p=0,002)$, dukungan tokoh masyarakat $(p=0,000)$, dukungan kewenangan $(p=0,018)$, kejelasan kebijakan $(p=0,000)$, dan konsistensi kebijakan $(p=0,040)$ merupakan faktor-faktor yang memiliki hubungan dengan kepatuhan masyarakat terhadap kebijakan PKM di Kota Semarang.
\end{abstract}

Kata kunci: COVID-19 ; Kebijakan Pembatasan Kegiatan Masyarakat ; Kepatuhan

\begin{abstract}
[DETERMINANTS OF SEMARANG CITY COMMUNITY COMPLIANCE WITH COMMUNITY ACTIVITIES RESTRICTIONS POLICY IN PREVENTION OF COVID-19 SPREADING] Semarang is the city with the highest number of COVID-19 cases in Central Java. To prevent the spread of COVID-19, the Community Activity Restriction policy was implemented. However, there are still many people who do not comply with the policy so that the number of COVID-19 cases in Semarang City is increasing. This study was conducted to determine the factors that have a relationship with community compliance with Community Activity Restriction policies in Semarang City. The type of research used is quantitative with a cross-sectional design. A total of 140 respondents were obtained through the accidental sampling method. Data analysis was performed univariate and bivariate using non-parametric statistical tests. The results showed that attitudes $(p=0.039)$, infrastructure $(p=0.002)$, supervision $(p=0.002)$, support from community leaders $(p=0.000)$, support from authority $(p=0.018)$, policy clarity $(p=0.000)$, and policy consistency $(p=0.040)$ are factors that have a relationship with community compliance with PKM policies in Semarang City.
\end{abstract}

Keywords: COVID-19 ; Community Activities Restrictions Policy ; Compliance

\section{Pendahuluan}

Pandemi Coronavirus Disease 2019 (COVID19) yang terjadi pada awal Maret 2020 telah menggemparkan seluruh dunia. Penyakit

\footnotetext{
*) Correspondence Author (Chandrika Fahira Quamila)

E-mail: chandrikafahira@gmail.com
}

tersebut disebabkan oleh infeksi dari virus corona jenis baru, yaitu Severe Acute Respiratory Syndrome Coronavirus-2 (SARS-CoV-2). Virus ini berasal dari Kota Wuhan, Provinsi Hubei, China (Yuliana, 2020). Virus tersebut dapat menular melalui percikan bersin atau batuk dari penderita yang kemudian masuk ke dalam mulut, hidung, atau 
mata orang lain. Penularan langsung antar manusia mengakibatkan virus ini menyebar dengan sangat luas dan cepat di seluruh dunia, termasuk Indonesia (Susilo et al., 2020).

Hingga Februari 2021, Jawa Tengah merupakan salah satu provinsi di Indonesia yang berada diurutan tiga besar dengan kasus COVID19 tertinggi, yaitu sebanyak 153.662 (Dinas Kesehatan Provinsi Jawa Tengah, 2021). Lalu, kasus COVID-19 di Jawa Tengah paling banyak ditemukan di Kota Semarang dengan jumlah kasus mencapai 31.154 (Dinas Kesehatan Kota Semarang, 2021).

Guna mencegah penyebaran COVID-19, Pemerintah Kota Semarang membuat kebijakan Pembatasan Kegiatan Masyarakat (PKM). Kebijakan ini berlaku berdasarkan Keputusan Walikota Semarang Nomor 443/417 Tahun 2020 dan diatur dalam Peraturan Walikota Semarang Nomor 28 Tahun 2020. Menurut peraturan tersebut, PKM merupakan upaya pembatasan aktivitas masyarakat di luar rumah yang wajib dilakukan oleh setiap orang yang berdomisili atau berkegiatan di Kota Semarang. Pelaksanaan PKM terdiri dari beralihnya kegiatan sekolah dan bekerja, pembatasan kegiatan di tempat umum, keagamaan, olahraga, sosial dan budaya, pernikahan, pemakaman serta pergerakan masyarakat dengan moda transportasi.

Namun sejak kebijakan PKM diterapkan, jumlah kasus COVID-19 di Kota Semarang terus bertambah. Pada Desember 2020, terdapat sebanyak 19.958 kasus yang kemudian meningkat menjadi 25.598 kasus pada Januari 2021 hingga mencapai 31.154 kasus pada Februari 2021 (Dinas Kesehatan Kota Semarang, 2021). Selain itu, masih ditemukan pula masyarakat di Kota Semarang yang tidak patuh terhadap kebijakan tersebut. Hal ini dapat dilihat dari hasil operasi pelanggaran protokol kesehatan yang meningkat dari 1.950 kasus pada Desember 2020 lalu menjadi 3.092 kasus pada Januari 2021 dan terus bertambah hingga 3.347 kasus pada Februari 2021 (Dinas Kesehatan Provinsi Jawa Tengah, 2021). Berdasarkan hasil pengamatan protokol kesehatan yang dilakukan oleh Dinas Kesehatan Kota Semarang pada November 2020, didapatkan hasil bahwa tingkat kepatuhan masyarakat terhadap penerapan jaga jarak menurun dari 70\% menjadi $66 \%$. Lalu, kepatuhan masyarakat untuk memakai masker dan mencuci tangan juga mengalami penurunan dari $80 \%$ menjadi $70 \%$. Hal-hal tersebut dapat terjadi karena kurangnya kepatuhan masyarakat terhadap kebijakan PKM.

Penelitian mengenai kepatuhan masyarakat terhadap kebijakan PKM belum pernah dilakukan sebelumnya. Namun terdapat penelitian yang sejenis, yaitu penelitian mengenai kepatuhan masyarakat terhadap kebijakan PSBB yang dilakukan oleh Wiranti, dimana disebutkan bahwa terdapat hubungan antara jenis kelamin, tingkat pendidikan, pengetahuan, dan sikap dengan kepatuhan masyarakat. Selain itu, terdapat penelitian Novi Afrianti mengenai kepatuhan masyarakat terhadap protokol kesehatan COVID-19, dimana usia, pendidikan, pengetahuan, sikap, dan motivasi dinyatakan memiliki hubungan dengan kepatuhan masyarakat.

Perbedaan penelitian ini terletak pada subjek, lokasi dan variabel penelitian. Pada penelitian Wiranti, subjeknya adalah masyarakat Kota Depok yang berlokasi di Kota Depok dan variabel penelitiannya berupa kepatuhan masyarakat, jenis kelamin, tingkat pendidikan, pekerjaan, pengetahuan, sikap, sarana prasarana, pengawasan, dukungan pemerintah, dan dukungan tokoh masyarakat (Wiranti, Sriatmi, \& Kusumastuti, 2020). Sedangkan pada penelitian Novi Afrianti, subjeknya adalah masyarakat Kota Banda Aceh yang berlokasi di Kota Banda Aceh dan variabel penelitiannya berupa kepatuhan masyarakat, faktor demografi, pengetahuan, sikap, dan motivasi (Afrianti \& Rahmiati, 2021).

Tujuan dari dilakukannya penelitian ini adalah untuk mengetahui faktor-faktor yang berhubungan dengan kepatuhan masyarakat terhadap kebijakan PKM di Kota Semarang.

\section{Metode}

Penelitian ini merupakan penelitian kuantitatif dengan desain penelitian cross sectional. Populasi dalam penelitian ini adalah seluruh masyarakat yang berdomisili atau berkegiatan di Kota Semarang. Sampel penelitian dihitung menggunakan rumus Lemeshow dan dihasilkan jumlah sampel minimal sebanyak 100 orang. Sebelum mengumpulkan data, dilakukan uji validitas dan reliabilitas terlebih dahulu kepada 30 orang responden diluar sampel penelitian. Pengambilan sampel dilakukan menggunakan teknik accidental sampling dengan instrumen penelitian berupa kuesioner yang terdiri dari 5 butir pertanyaan berskala guttman dan 45 butir pertanyaan berskala likert yang dibuat melalui google form dan disebarluaskan secara daring sehingga didapatkan sampel penelitian sebanyak 140 responden.

Variabel bebas yang diteliti antara lain pengetahuan, sikap, sarana prasarana, pengawasan, dukungan tokoh masyarakat, 
dukungan kewenangan, kejelasan kebijakan dan konsistensi kebijakan. Sedangkan, variabel terikatnya adalah kepatuhan masyarakat terhadap kebijakan PKM. Data penelitian dianalisis secara univariat guna menghasilkan distribusi frekuensi pada setiap variabel dan dianalisis secara bivariat guna mencari hubungan antara variabel bebas dengan variabel terikat. Uji statistik yang digunakan ialah uji non-parametrik berupa Rank Spearman karena data berkategori ordinal. Interpretasi data berdasarkan nilai $\mathrm{p}(p$ value), jika nilai $\mathrm{p}<0,05$ maka ada hubungan yang signifikan antara kedua variabel, begitupun sebaliknya.

Penelitian ini dilakukan pada bulan Maret April 2021 di Kota Semarang dan telah dinyatakan lolos kaji etik berdasarkan sertifikat yang dikeluarkan oleh Komisi Etik Penelitian Kesehatan Fakultas Kesehatan Masyarakat Universitas Diponegoro dengan nomor 122/EA/KEPK-FKM/2021.

\section{Hasil dan Pembahasan}

Data umum responden dalam penelitian ini adalah responden terbanyak adalah perempuan 96 respnden $(68,6 \%)$, berusia $17-25$ tahun $(62,1 \%)$, berpendidikan menengah $(55,0 \%)$, tidak bekerja $(50,7 \%)$, berstatus sebagai warga Kota Semarang $(75,0 \%)$.

Tabel 1. Distribusi Frekuensi Karakteristik Responden

\begin{tabular}{lcc}
\hline Karakteristik Responden & $\begin{array}{c}\text { Frekuensi } \\
\text { (n) }\end{array}$ & $\begin{array}{c}\text { Persentase } \\
\text { (\%) }\end{array}$ \\
\hline Jenis Kelamin & 44 & 31,4 \\
\hline Laki-laki & 96 & 68,6 \\
Perempuan & & \\
\hline Usia & 87 & 62,1 \\
\hline Remaja Akhir (17 - 25 tahun) & 14 & 10,0 \\
Dewasa Awal (26 - 35 tahun) & 24 & 17,1 \\
Dewasa Akhir (36 - 45 tahun) & 14 & 10,0 \\
Lansia Awal (46 - 55 tahun) & 1 & 0,7 \\
Lansia Akhir (56 - 65 tahun) & & \\
\hline Tingkat Pendidikan & 1 & 0,7 \\
\hline Dasar (Tamat SD) & 77 & 55,0 \\
Menengah (Tamat SMP/SMA) & 62 & 44,3 \\
Tinggi (Tamat PT) & & \\
\hline Pekerjaan & 71 & 50,7 \\
\hline Tidak Bekerja & 69 & 49,3 \\
Bekerja & & \\
\hline Status Kependudukan & 105 & 25,0 \\
\hline Warga Kota Semarang & 35 & \\
Bukan Warga Kota Semarang & & \\
\hline
\end{tabular}

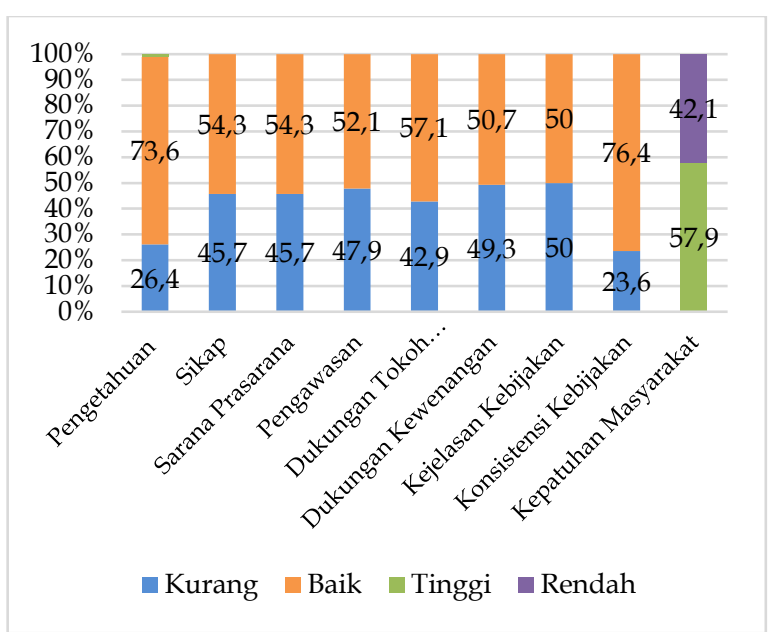

Gambar 1. Distribusi Frekuensi Variabel Penelitian

Berdasarkan Gambar 1. terlihat bahwa sebagian besar responden memiliki pengetahuan yang baik mengenai kebijakan PKM (73,6\%), merasakan adanya dukungan tokoh masyarakat yang baik terhadap kebijakan PKM $(57,1 \%)$, dan menilai bahwa konsistensi dalam kebijakan PKM sudah cukup baik (76,4\%). Lalu, responden dengan sikap $(54,3 \%)$, sarana prasarana $(54,3 \%)$, pengawasan $(52,1 \%)$, dan dukungan kewenanganan yang baik (50,7\%), memiliki frekuensi sedikit lebih banyak jika dibandingkan dengan yang kurang baik. Sedangkan, responden dengan kejelasan kebijakan yang baik maupun yang kurang baik memiliki proporsi yang sama besar, yaitu 50\%. Meskipun terdapat banyak responden dengan kepatuhan tinggi, namun masih terdapat sebanyak $42,1 \%$ responden dengan kepatuhan yang rendah terhadap kebijakan PKM.

Tabel 2. menyajikan hubungan antara variabel bebas dengan variabel terikat. Dapat dilihat bahwa responden dengan kepatuhan tinggi terhadap kebijakan PKM lebih banyak dilakukan oleh responden dengan pengetahuan yang kurang baik $(64,9 \%)$. Namun, responden pada kategori kepatuhan tinggi juga lebih banyak dilakukan oleh responden dengan sikap yang baik $(65,8 \%)$, tersedianya sarana prasarana yang mendukung $(69,7 \%)$, adanya pengawasan yang baik $(69,9 \%)$, adanya dukungan tokoh masyarakat $(72,5 \%)$ dan dukungan kewenangan yang baik $(67,6 \%)$, serta adanya penilaian terhadap kejelasan $(77,1 \%)$ dan konsistensi kebijakan yang baik $(62,6 \%)$. 
Tabel 2. Distribusi Hubungan Variabel Bebas dengan Variabel Terikat

\begin{tabular}{|c|c|c|c|c|c|c|}
\hline \multirow{3}{*}{ Variabel } & \multicolumn{4}{|c|}{ Kepatuhan Masyarakat } & \multirow{3}{*}{$p$-value (p) } & \multirow{3}{*}{ OR } \\
\hline & \multicolumn{2}{|c|}{ Rendah } & \multicolumn{2}{|c|}{ Tinggi } & & \\
\hline & Frekuensi (n) & Persentase $(\%)$ & Frekuensi (n) & Persentase $(\%)$ & & \\
\hline \multicolumn{7}{|l|}{ Pengetahuan } \\
\hline Kurang Baik & 13 & 35,1 & 24 & 64,9 & \multirow{2}{*}{0,318} & \multirow{2}{*}{0,671} \\
\hline Baik & 46 & 44,7 & 57 & 55,3 & & \\
\hline \multicolumn{7}{|l|}{ Sikap } \\
\hline Kurang Baik & 33 & 51,6 & 31 & 48,4 & \multirow{2}{*}{0,039} & \multirow{2}{*}{2,047} \\
\hline Baik & 26 & 34,2 & 50 & 65,8 & & \\
\hline \multicolumn{7}{|c|}{ Sarana Prasarana } \\
\hline Kurang Baik & 36 & 56,3 & 28 & 43,8 & \multirow{2}{*}{0,002} & \multirow{2}{*}{2,963} \\
\hline Baik & 23 & 30,3 & 53 & 69,7 & & \\
\hline \multicolumn{7}{|l|}{ Pengawasan } \\
\hline Kurang Baik & 37 & 55,2 & 30 & 44,8 & \multirow{2}{*}{0,002} & \multirow{2}{*}{2,859} \\
\hline Baik & 22 & 30,1 & 51 & 69,9 & & \\
\hline \multicolumn{7}{|c|}{ Dukungan Tokoh Masyarakat } \\
\hline Kurang Baik & 37 & 61,7 & 23 & 38,3 & \multirow{2}{*}{0,000} & \multirow{2}{*}{4,241} \\
\hline Baik & 22 & 27,5 & 58 & 72,5 & & \\
\hline \multicolumn{7}{|c|}{ Dukungan Kewenangan } \\
\hline Kurang Baik & 36 & 52,2 & 33 & 47,8 & \multirow{2}{*}{0,018} & \multirow{2}{*}{2,277} \\
\hline Baik & 23 & 32,4 & 48 & 67,6 & & \\
\hline \multicolumn{7}{|c|}{ Kejelasan Kebijakan } \\
\hline Kurang Baik & 43 & 61,4 & 27 & 38,6 & \multirow{2}{*}{0,000} & \multirow{2}{*}{5,375} \\
\hline Baik & 16 & 22,9 & 54 & 77,1 & & \\
\hline \multicolumn{7}{|c|}{ Konsistensi Kebijakan } \\
\hline Kurang Baik & 19 & 57,6 & 14 & 42,4 & \multirow{2}{*}{0,040} & \multirow{2}{*}{2,273} \\
\hline Baik & 40 & 37,4 & 67 & 62,6 & & \\
\hline
\end{tabular}

Berdasarkan hasil uji hubungan, dapat diketahui bahwa terdapat satu variabel yang memiliki hubungan yang tidak signifikan dengan kepatuhan masyarakat terhadap kebijakan PKM, yaitu pengetahuan. Sedangkan variabel lainnya, seperti sikap, sarana prasarana, pengawasan, dukungan tokoh masyarakat, dukungan kewenangan, kejelasan kebijakan, dan konsistensi kebijakan dinyatakan memiliki hubungan yang signifikan dengan kepatuhan masyarakat terhadap kebijakan PKM berdasarkan $p$-value nya. Berikut adalah hasil dan juga pembahasan dari setiap hubungan antara variabel bebas dan variabel terikat yang diteliti.

\section{a. Hubungan Pengetahuan dengan Kepatuhan Masyarakat terhadap Kebijakan PKM}

Hasil penelitian menunjukkan bahwa responden yang kurang patuh terhadap kebijakan PKM lebih banyak dilakukan oleh responden dengan pengetahuan yang baik. Meskipun sebagian besar responden dinyatakan memiliki pengetahuan yang baik mengenai kebijakan PKM, namun masih banyak yang tidak memahami pelaksanaannya, seperti alasan diberlakukannya kebijakan tersebut, jenis kegiatan yang dibatasi, sanksi terhadap pelanggaran PKM serta kewajiban yang harus dilakukan ketika keluar rumah selama pelaksanaan PKM.

Berdasarkan hasil jawaban responden, masih terdapat responden yang keliru terhadap penerapan protokol kesehatan saat berada di luar rumah, seperti penggunaan sarung tangan. Penelitian yang dilakukan oleh Gobi menyatakan tidak terdapat bukti klinis yang menunjukkan bahwa penggunaan sarung tangan di luar kebutuhan medis dapat mencegah infeksi COVID-19 (Gunasekaran, 2020). Selain itu, berdasarkan artikel yang ditulis oleh Linda Nazarko, disebutkan bahwa sebaiknya penggunaan sarung tangan hanya dilakukan untuk aktivitas yang berisiko tinggi terpapar COVID-19 dan tidak digunakan pada aktivitas harian, seperti berbelanja kebutuhan pokok (Nazarko, 2020).

Pengetahuan terdiri dari enam tingkatan, antara lain tahu, memahami, aplikasi, analisis, sintesis dan evaluasi (Notoatmodjo, 2014). Sebagian besar responden yang tidak paham terhadap pelaksanaan PKM tersebut, kemungkinan masih berada pada tingkatan pertama dalam pengetahuan, yaitu tahu sehingga meskipun sebagian besar dari responden memiliki pengetahuan yang baik, namun jawaban mereka menunjukkan bahwa 
pengetahuan tersebut belum benar-benar baik karena mereka hanya mengetahui pengertian dari PKM saja dan tidak memahami pelaksanaannya.

Hasil uji Rank Spearman menunjukkan bahwa tidak terdapat hubungan antara pengetahuan dengan kepatuhan masyarakat terhadap kebijakan PKM di Kota Semarang $(p=0,318)$. Hal ini dapat terjadi karena pengetahuan tersebut tidak didukung oleh adanya kesadaran diri atau self-awareness untuk mematuhi kebijakan PKM. Menurut penelitian Ulfa Indriyani, dinyatakan bahwa terdapat hubungan antara self-awareness dengan kedisiplinan memakai masker di masa new normal. Penelitian tersebut juga menyatakan jika seseorang memiliki kesadaran diri yang tinggi, maka orang tersebut akan memiliki perilaku yang baik pula, dalam hal ini ialah perilaku patuh terhadap kebijakan PKM (Indriyani, 2020). Penelitian ini sejalan dengan penelitian yang dilakukan oleh Ahmad Sa'roni, dimana tidak terdapat hubungan antara pengetahuan dengan kepatuhan terhadap kebijakan (Sa'roni, Sriatmi, \& Arso, 2018).

Berdasarkan perhitungan dari ukuran hubungan atau Odds Ratio (OR), didapatkan hasil bahwa masyarakat dengan pengetahuan yang baik memiliki kemungkinan sebesar 0,671 kali lipat untuk lebih patuh terhadap kebijakan PKM dibandingkan masyarakat dengan pengetahuan yang kurang baik. Hal ini sejalan dengan hasil penelitian Yulyana Kusuma Dewi, dimana pegawai dengan pengetahuan tentang peraturan daerah yang baik memiliki kemungkinan sebesar 3,680 kali lipat untuk lebih patuh terhadap kebijakan Kawasan Tanpa Rokok (KTR) dibandingkan pegawai dengan pengetahuan yang kurang (Dewi, Nuraini, \& Lionardo, 2018).

\section{b. Hubungan Sikap dengan Kepatuhan Masyarakat terhadap Kebijakan PKM}

Hasil penelitian menunjukkan bahwa responden dengan kepatuhan rendah lebih banyak dilakukan oleh responden dengan sikap yang kurang mendukung kebijakan PKM. Berdasarkan hasil jawaban responden, masih terdapat banyak responden yang ragu terhadap kemampuan dari kebijakan PKM dalam mencegah penyebaran COVID-19. Hal ini mungkin terjadi karena terdapat beberapa faktor yang dapat mempengaruhi pembentukan sikap, seperti kepercayaan dan pengalaman pribadi (Notoatmodjo, 2014).

Jika seseorang percaya bahwa keputusan pemerintah dalam menerapkan kebijakan PKM telah efektif dalam mencegah penyebaran COVID-19, maka orang tersebut akan bersikap patuh terhadap kebijakan tersebut. Hal ini sejalan dengan penelitian R.K Webster yang menyatakan bahwa salah satu faktor yang dapat meningkatkan kepatuhan seseorang terhadap karantina ialah adanya kepercayaan pada keputusan pemerintah (Webster et al., 2020). Selain itu, Darmiyati Zuchdi dalam Muhtadi menyebutkan bahwa seseorang akan cenderung membentuk sikap negatif terhadap suatu objek dalam dirinya, jika ia tidak memiliki pengalaman dengan objek tersebut (Muhtadi, 2011). Sebelum pandemi COVID-19 terjadi, Kota Semarang belum pernah menerapkan kebijakan yang membatasi kegiatan masyarakatnya sehingga dengan nihilnya pengalaman tersebut dapat membentuk sikap negatif pada masyarakat terhadap kebijakan PKM.

Berdasarkan hasil uji Rank Spearman, dinyatakan terdapat hubungan yang signifikan antara sikap dengan kepatuhan masyarakat terhadap kebijakan PKM di Kota Semarang $(p=0,039)$. Penelitian ini sejalan dengan penelitian yang dilakukan oleh Novi Afrianti, Ahmad Sa'roni, dan Wiranti dimana terdapat hubungan antara sikap dengan kepatuhan terhadap kebijakan. (Afrianti \& Rahmiati, 2021), (Sa'roni et al., 2018), (Wiranti et al., 2020).

Berdasarkan perhitungan dari ukuran hubungan (OR), didapatkan hasil bahwa masyarakat dengan sikap yang baik memiliki kemungkinan sebesar 2,047 kali lipat untuk lebih patuh terhadap kebijakan PKM dibandingkan masyarakat dengan sikap yang kurang baik.

\section{c. Hubungan Sarana Prasarana dengan Kepatuhan Masyarakat terhadap Kebijakan PKM}

Penelitian ini memiliki hasil bahwa responden yang kurang patuh terhadap kebijakan PKM lebih banyak dilakukan oleh responden dengan sarana prasarana yang kurang mendukung. Hasil jawaban responden menunjukkan masih terdapat responden yang tidak merasakan adanya pembatasan pengunjung pada fasilitas kesehatan selama pelaksanaan PKM. Hal ini 
dapat terjadi karena terdapat perbedaan penerapan kebijakan pada setiap fasilitas kesehatan selama pandemi COVID-19. Berdasarkan panduan teknis pelayanan rumah sakit pada masa adaptasi kebiasaan baru, disebutkan bahwa rumah sakit perlu melakukan prosedur penerimaan pasien yang lebih ketat dan sesuai dengan standar protokol pencegahan dan pengendalian infeksi, salah satunya adalah dengan membatasi pengunjung atau pendamping pasien (Kementerian Kesehatan RI, 2020). Sedangkan dalam petunjuk teknis pelayanan puskesmas pada masa pandemi COVID-19, disebutkan bahwa puskesmas dihimbau untuk melakukan pembatasan atau penundaan terhadap pelayanan Upaya Kesehatan Perorangan (UKP) guna mengurangi risiko penularan COVID-19 (Kementerian Kesehatan RI, 2020).

Hasil uji Rank Spearman menunjukkan bahwa terdapat hubungan antara sarana prasarana dengan kepatuhan masyarakat terhadap kebijakan PKM di Kota Semarang $(p=0,002)$. Penelitian ini sejalan dengan penelitian yang dilakukan oleh Ahmad Sa'roni, dimana terdapat hubungan antara sarana prasarana dengan kepatuhan terhadap kebijakan (Sa'roni et al., 2018).

Berdasarkan perhitungan dari ukuran hubungan (OR), didapatkan hasil bahwa masyarakat dengan sarana prasarana yang baik memiliki kemungkinan sebesar 2,963 kali lipat untuk lebih patuh terhadap kebijakan PKM dibandingkan masyarakat dengan sarana prasarana yang kurang baik. Hal ini sejalan dengan hasil penelitian Yulyana Kusuma Dewi, dimana pegawai yang didukung oleh adanya sarana prasarana memiliki kemungkinan sebesar 5,143 kali lipat untuk lebih patuh terhadap kebijakan KTR dibandingkan dengan pegawai yang tidak didukung oleh adanya sarana prasarana (Dewi, Nuraini, \& Lionardo, 2018).

\section{d. Hubungan Pengawasan dengan Kepatuhan Masyarakat terhadap Kebijakan PKM}

Hasil penelitian menunjukkan bahwa responden dengan kepatuhan rendah lebih banyak dilakukan oleh responden dengan pengawasan yang kurang baik. Berdasarkan hasil jawaban responden, masih terdapat responden yang menilai bahwa pengawasan terhadap pelaksanaan PKM belum dilakukan secara ketat. Namun pada Januari 2021, Wakil Walikota Semarang menyatakan bahwa
Pemerintah Kota Semarang telah memperketat pengawasan terhadap PKM dengan mengerahkan petugas patroli yang akan menerapkan sanksi bagi pelanggar PKM secara tegas. Meskipun Walikota Semarang telah menyatakan pelonggaran terhadap pelaksanaan PKM pada Februari 2021, pengawasan terhadap PKM akan tetap dilakukan mulai dari tingkat kelurahan dengan melibatkan Lurah, Bintara Pembina Desa (Babinsa) serta Bhayangkara Pembina Keamanan dan Ketertiban Masyarakat (Babinkamtibmas).

Berdasarkan hasil uji Rank Spearman, dinyatakan terdapat hubungan yang signifikan antara pengawasan dengan kepatuhan masyarakat terhadap kebijakan PKM di Kota Semarang $(p=0,002)$. Penelitian ini sejalan dengan penelitian yang dilakukan oleh Ahmad Sa'roni, dimana terdapat hubungan antara pengawasan dengan kepatuhan terhadap kebijakan (Sa'roni et al., 2018).

Berdasarkan perhitungan dari ukuran hubungan (OR), didapatkan hasil bahwa masyarakat dengan pengawasan yang baik memiliki kemungkinan sebesar 2,859 kali lipat untuk lebih patuh terhadap kebijakan PKM dibandingkan masyarakat dengan pengawasan yang kurang baik. Hal ini sejalan dengan hasil penelitian Yulyana Kusuma Dewi, dimana pegawai yang didukung oleh adanya penerapan sanksi memiliki kemungkinan sebesar 10,278 kali lipat untuk lebih patuh terhadap kebijakan KTR dibandingkan dengan pegawai yang tidak didukung oleh adanya penerapan sanksi (Dewi, Nuraini, \& Lionardo, 2018).

\section{e. Hubungan Dukungan Tokoh Masyarakat dengan Kepatuhan Masyarakat terhadap Kebijakan PKM}

Penelitian ini menunjukkan hasil bahwa responden yang kurang patuh terhadap kebijakan PKM lebih banyak dilakukan oleh responden dengan dukungan dari tokoh masyarakat yang kurang baik. Berdasarkan hasil jawaban responden, sebagian besar responden telah merasakan adanya dukungan terhadap kebijakan PKM dari tokoh masyarakat dan tokoh agama di sekitar tempat tinggal mereka. Dukungan tersebut berupa himbauan untuk tetap berada di rumah dan pembatasan kegiatan yang berisiko menciptakan kerumunan. 
Dalam penelitian ini, dukungan tokoh masyarakat, termasuk tokoh agama merupakan salah satu faktor yang dapat membentuk perilaku patuh pada masyarakat terhadap kebijakan PKM. Hal ini didukung oleh ungkapan Budiarjo dalam Rosidin yang menyatakan bahwa tokoh masyarakat berperan penting dalam mempengaruhi orang atau kelompok lain sesuai dengan keinginan dirinya (Rosidin, Rahayuwati, \& Herawati, 2020). Apabila tokoh masyarakat patuh terhadap kebijakan PKM, maka mereka dapat mempengaruhi masyarakat disekitarnya untuk melakukan hal yang sama. Selain itu, Pemerintah Kota Semarang pun telah menghimbau masyarakat untuk berpartisipasi dalam upaya menurunkan kasus COVID-19 dengan saling mengingatkan penerapan protokol kesehatan dan melakukan kegiatan yang dapat mendukung pencegahan penyebaran COVID-19.

Hasil uji Rank Spearman menunjukkan bahwa terdapat hubungan antara dukungan tokoh masyarakat dengan kepatuhan masyarakat terhadap kebijakan PKM di Kota Semarang $(p=0,000)$. Penelitian ini sejalan dengan penelitian yang dilakukan oleh Gayatri Sekar Pertiwi, dimana terdapat hubungan antara dukungan tokoh masyarakat dengan perilaku physical distancing (Pertiwi \& Budiono, 2021).

Berdasarkan perhitungan dari ukuran hubungan (OR), didapatkan hasil bahwa masyarakat dengan dukungan tokoh masyarakat yang baik memiliki kemungkinan sebesar 4,241 kali lipat untuk lebih patuh terhadap kebijakan PKM dibandingkan masyarakat dengan dukungan tokoh masyarakat yang kurang baik. Hal ini sejalan dengan hasil penelitian Yulyana Kusuma Dewi, dimana pegawai yang didukung oleh adanya dukungan atasan memiliki kemungkinan sebesar 5,093 kali lipat untuk lebih patuh terhadap kebijakan KTR dibandingkan dengan pegawai yang tidak didukung oleh adanya dukungan atasan (Dewi, Nuraini, \& Lionardo, 2018).

\section{f. Hubungan Dukungan Kewenangan dengan Kepatuhan Masyarakat terhadap Kebijakan PKM}

Hasil penelitian menunjukkan bahwa responden dengan kepatuhan rendah lebih banyak dilakukan oleh responden dengan dukungan kewenanganan yang kurang baik.
Berdasarkan hasil jawaban responden, masih ditemukan responden yang tidak merasakan adanya dukungan dalam bentuk bantuan sosial dari pemerintah. Menurut informasi data bantuan sosial COVID-19 di Semarang, Pemerintah Kota Semarang telah memberikan berbagai jenis bantuan sosial kepada masyarakatnya, seperti bantuan sosial PKH, bantuan sosial tunai (BST), bantuan program sembako (BPNT), bantuan presiden, bantuan provinsi, bantuan COVID19 kota, serta bantuan sembako perluasan (Dinas Kesehatan Kota Semarang, 2021). Hal ini dapat saja terjadi karena tidak semua masyarakat di Kota Semarang termasuk ke dalam kategori penerima bantuan sosial sehingga terdapat kemungkinan bahwa responden dalam penelitian ini tidak memenuhi kriteria sebagai penerima bantuan sosial tersebut.

Berdasarkan hasil uji Rank Spearman, dinyatakan terdapat hubungan antara dukungan kewenangan dengan kepatuhan masyarakat terhadap kebijakan PKM di Kota Semarang $(p=0,018)$. Penelitian ini sejalan dengan penelitian yang telah dilakukan oleh Yulyana Kusuma Dewi, dimana terdapat hubungan antara dukungan atasan dengan kepatuhan terhadap kebijakan (Dewi et al., 2018).

Berdasarkan perhitungan dari ukuran hubungan (OR), didapatkan hasil bahwa masyarakat dengan dukungan kewenangan yang baik memiliki kemungkinan sebesar 2,277 kali lipat untuk lebih patuh terhadap kebijakan PKM dibandingkan masyarakat dengan dukungan kewenangan yang kurang baik. Hal ini sejalan dengan hasil penelitian Yulyana Kusuma Dewi, dimana pegawai yang didukung oleh adanya dukungan atasan memiliki kemungkinan sebesar 5,093 kali lipat untuk lebih patuh terhadap kebijakan KTR dibandingkan dengan pegawai yang tidak didukung oleh adanya dukungan atasan (Dewi, Nuraini, \& Lionardo, 2018).

g. Hubungan Kejelasan Kebijakan dengan Kepatuhan Masyarakat terhadap Kebijakan PKM

Penelitian ini menunjukkan hasil bahwa responden yang kurang patuh terhadap kebijakan PKM lebih banyak dilakukan oleh responden yang menilai kejelasan dalam kebijakan kurang baik. Berdasarkan penelitian yang dilakukan oleh Merry G. 
Mangindaan, disebutkan bahwa isi kebijakan sebaiknya dijabarkan dalam ketetapan yang rinci dan jelas agar tidak menimbulkan interpretasi ganda sehingga mudah dipahami bagi kelompok sasaran (Mangindaan, Liando, \& Lengkong, 2019). Namun, hasil jawaban menunjukkan bahwa masih ada responden yang tidak memahami sanksi terhadap pelanggaran kebijakan PKM di Kota Semarang. Menurut Notoatmodjo, tahu merupakan tingkat pengetahuan sebelum memahami sehingga seseorang harus mengetahui suatu hal terlebih dahulu sebelum dapat memahaminya (Notoatmodjo, 2014). Hal ini didukung oleh fakta bahwa sebagian besar responden memang tidak mengetahui sanksi terhadap pelanggaran kebijakan PKM yang menyebabkan mereka menjadi tidak paham akan hal tersebut.

Hasil uji Rank Spearman menunjukkan bahwa terdapat hubungan antara kejelasan kebijakan dengan kepatuhan masyarakat terhadap kebijakan PKM di Kota Semarang $(p=0,000)$. Penelitian ini sejalan dengan penelitian yang dilakukan oleh Lia Kusumawardhani, dimana kejelasan informasi dan sanksi merupakan faktor yang dapat mempengaruhi kepatuhan dalam implementasi kebijakan (Kusumawardhani \& Manurung, 2013).

Berdasarkan perhitungan dari ukuran hubungan (OR), didapatkan hasil bahwa masyarakat dengan kejelasan kebijakan yang baik memiliki kemungkinan sebesar 5,375 kali lipat untuk lebih patuh terhadap kebijakan PKM dibandingkan masyarakat dengan kejelasan kebijakan yang kurang baik. Hal ini sejalan dengan hasil penelitian Yulyana Kusuma Dewi, dimana pegawai yang didukung oleh adanya penerapan sanksi memiliki kemungkinan sebesar 10,278 kali lipat untuk lebih patuh terhadap kebijakan KTR dibandingkan dengan pegawai yang tidak didukung oleh adanya penerapan sanksi (Dewi, Nuraini, \& Lionardo, 2018).

\section{h. Hubungan Konsistensi Kebijakan dengan Kepatuhan Masyarakat terhadap Kebijakan PKM}

Hasil penelitian menunjukkan bahwa responden dengan kepatuhan rendah terhadap kebijakan PKM lebih banyak dilakukan oleh responden yang menilai konsistensi dalam kebijakan kurang baik. Berdasarkan hasil jawaban responden, sebagian besar responden menyatakan bahwa konsistensi dalam kebijakan PKM sudah cukup baik. Namun, masih terdapat responden yang merasa bahwa penerapan sanksi bagi pelanggar kebijakan PKM tidak dilakukan secara tetap selama pelaksanaan PKM. Hal ini bisa saja terjadi karena berdasarkan data Dinas Kesehatan Kota Semarang, penerapan sanksi kepada pelanggar kebijakan PKM yang dilakukan melalui Operasi Yustisi Protokol Kesehatan memang tidak dilakukan setiap hari dan hanya dilakukan dibeberapa titik di wilayah Kota Semarang (Dinas Kesehatan Kota Semarang, 2021). Pelaksanaan pengawasan yang kurang konsisten tersebut dapat menyebabkan masyarakat menilai bahwa penerapan sanksi tidak dilakukan secara tetap.

Berdasarkan hasil uji Rank Spearman, dinyatakan terdapat hubungan antara konsistensi kebijakan dengan kepatuhan masyarakat terhadap kebijakan PKM di Kota Semarang $(p=0,040)$. Penelitian ini sejalan dengan penelitian yang telah dilakukan oleh Shabika Imany, dimana konsistensi kebijakan merupakan faktor yang mempengaruhi pemahaman pelaksana terhadap suatu kebijakan (Wiguna, 2020).

Berdasarkan perhitungan dari ukuran hubungan (OR), didapatkan hasil bahwa masyarakat dengan konsistensi kebijakan yang baik memiliki kemungkinan sebesar 2,273 kali lipat untuk lebih patuh terhadap kebijakan PKM dibandingkan masyarakat dengan konsistensi kebijakan yang kurang baik. Hal ini sejalan dengan hasil penelitian Yulyana Kusuma Dewi, dimana pegawai yang didukung oleh adanya penerapan sanksi memiliki kemungkinan sebesar 10,278 kali lipat untuk lebih patuh terhadap kebijakan KTR dibandingkan dengan pegawai yang tidak didukung oleh adanya penerapan sanksi (Dewi, Nuraini, \& Lionardo, 2018).

\section{Simpulan dan Saran}

Berdasarkan hasil dan pembahasan penelitian, dari delapan variabel yang diteliti, terdapat tujuh variabel yang memiliki hubungan dengan kepatuhan masyarakat terhadap kebijakan PKM di Kota Semarang, antara lain sikap, sarana prasarana, pengawasan, dukungan tokoh masyarakat, dukungan kewenangan, kejelasan kebijakan, dan konsistensi kebijakan. Upaya yang dapat dilakukan guna 
meningkatkan kepatuhan masyarakat terhadap kebijakan PKM di Kota Semarang adalah memberikan edukasi kepada masyarakat mengenai kebijakan PKM dengan bahasa yang sederhana, memberdayakan tokoh masyarakat sebagai koordinator dalam pelaksanaan sosialisasi mengenai kebijakan PKM, menyebarluaskan informasi terkait efektivitas kebijakan PKM melalui media sosial atau situs web milik pemerintah, meningkatkan pelaksanaan Operasi Yustisi Protokol Kesehatan secara rutin, serta sebagai masyarakat untuk mencari tahu dan membaca informasi mengenai kebijakan PKM melalui situs web semarangkota.go.id.

\section{Ucapan Terima Kasih}

Ucapan terima kasih ditujukan kepada seluruh pihak yang telah membantu pelaksanaan penelitian, terutama responden yang telah bersedia mengisi kuesioner penelitian. Terima kasih juga disampaikan kepada dosen pembimbing serta dosen penguji yang telah membimbing selama proses penelitian dan membantu dalam penyempurnaan artikel ini.

\section{Daftar Pustaka}

Afrianti, N., \& Rahmiati, C. (2021). Faktor-Faktor yang Mempengaruhi Kepatuhan Masyarakat terhadap Protokol Kesehatan COVID-19. Jurnal Ilmiah Permas: Jurnal Ilmiah STIKES Kendal, 11(1), 113-124.

Dashboard Data Kegiatan Kota Semarang. (2021). Retrieved May 3, 2021, from Dinas Kesehatan Kota Semarang website: https://siagacorona.semarangkota.go. id/

Dewi, Y. K., Nuraini, F., \& Lionardo, A. (2018). Analisis Faktor-Faktor yang Mempengaruhi Kepatuhan Pegawai terhadap Kebijakan Kawasan Tanpa Rokok di Kantor Satuan Polisi Pamong Praja Kota Palembang. Sriwijaya Journal of Medicine, 1(1), 8-15.

Gunasekaran, G. H. (2020). Prevalence and acceptance of glove wearing practice among general population when visiting high risk are during local COVID-19 outbreak. MedRxiv, 5(1), 14.

Hasil Operasi Pelanggaran Protokol Kesehatan: Pelanggaran Berdasarkan Kabupaten/ Kota. (2021). Retrieved January 22, 2021, from Jateng Tanggap COVID-19 website: https://corona.jatengprov.go.id/prot okol-kesehatan

Indriyani, U. (2020). Hubungan Antara Self Awareness dengan Kedisiplinan Memakai Masker di Masa New Normal pada Pedagang di Pasar Suwatu Tanon Sragen. Institut Agama Islam Negeri Surakarta.

Informasi Coronavirus (COVID-19) Semarang. (2020). Retrieved from Dinas Kesehatan Kota Semarang website: https://siagacorona.semarangkota.go. id/halaman/covid19

Informasi Data Bantuan Sosial (COVID-19) Semarang. (2021). Retrieved April 23, 2021, from semarangkota.go.id website: http://infobansos.semarangkota.go.id /

Kusumawardhani, L., \& Manurung, L. (2013). Faktor-Faktor yang Mempengaruhi Kepatuhan Masyarakat dalam Implementasi Kebijakan IMB di Kota Depok. 15.

Mangindaan, M. G., Liando, D., \& Lengkong, J. (2019). Implementasi Kebijakan Pengangkatan Jabatan Fungsional Tertentu Analis Kepegawaian di Badan Kepegawaian Daerah Provinsi Sulawesi Utara. Jurnal Administrasi Publik, 5(86), 47-58.

Muhtadi, A. (2011). Pengembangan Sikap dan Perilaku Siswa yang Bermoral dalam Kegiatan Pembelajaran di Sekolah. Majalah Ilmiah Pembelajaran, 7(1), 96107.

Nazarko, L. (2020). Covid 19 and gloves: When to wear and when not to wear. Nigerian Journal of Environmental Sciences and Technology, 4(1), 1-7. https://doi.org/10.36263/nijest.2020. 01

Notoatmodjo, S. (2014). Promosi Kesehatan dan Perilaku Kesehatan. Jakarta: Rineka Cipta.

Panduan Teknis Pelayanan Rumah Sakit pada Masa Adaptasi Kebiasaan Baru. (2020). In Kementerian Kesehatan RI. Jakarta: Direktorat Jenderal Pelayanan Kesehatan, Kementerian Kesehatan RI.

Pertiwi, G. S., \& Budiono, I. (2021). Perilaku Physical Distancing Masyarakat pada Masa Pandemi Covid-19. Indonesian Journal of Public Health and Nutrition, 1(1), 90-100.

Petunjuk Teknis Pelayanan Puskesmas pada Masa Pandemi COVID-19. (2020). In Kementerian Kesehatan RI. Jakarta: 
Direktorat Jenderal Pelayanan Kesehatan, Kementerian Kesehatan RI.

Rosidin, U., Rahayuwati, L., \& Herawati, E. (2020). Perilaku dan Peran Tokoh Masyarakat dalam Pencegahan dan Penanggulangan Pandemi Covid-19 di Desa Jayaraga, Kabupaten Garut. Indonesian Journal of Anthropology, 5(1), 42-50.

https://doi.org/10.24198/umbara.v5i 1.28187

Sa'roni, A., Sriatmi, A., \& Arso, S. P. (2018). Faktor-Faktor Yang Berhubungan dengan Kepatuhan Masyarakat Desa Winong Kecamatan Pati Kabupaten Pati dalam Pelaksanaan Peraturan Daerah Nomor 10 Tahun 2014 Tentang Kawasan Tanpa Rokok. Jurnal Kesehatan Masyarakat, 6(4), 1-9.

Statistik Kasus COVID-19 Jawa Tengah. (2020). Retrieved December 28, 2020, from Jateng Tanggap COVID-19 website: https://corona.jatengprov.go.id/data

Susilo, A., Rumende, C. M., Pitoyo, C. W., Santoso, W. D., Yulianti, M., Herikurniawan, H., ... Yunihastuti, E. (2020). Coronavirus Disease 2019:
Tinjauan Literatur Terkini. Jurnal Penyakit Dalam Indonesia, 7(1), 45-67.

Webster, R. K., Brooks, S. K., Smith, L. E., Woodland, L., Wessely, S., \& Rubin, G. J. (2020). How to improve adherence with quarantine: rapid review of the evidence. Public Health, 182, 163-169. https://doi.org/10.1016/j.puhe.2020.0 3.007

Wiguna, S. I. P. (2020). Implementasi Kebijakan Pembentukan Balai Kesehatan Masyarakat (Balkesmas) dalam Pelaksanaan Rujukan UKM di Balkesmas Wilayah Magelang.

Wiranti, Sriatmi, A., \& Kusumastuti, W. (2020). Determinan Kepatuhan Masyarakat Kota Depok terhadap Kebijakan Pembatasan Sosial Berskala Besar dalam Pencegahan COVID-19. Jurnal Kebijakan Kesehatan Indonesia, 9(3), 117124.

Yuliana. (2020). Corona virus diseases (Covid 19); Sebuah tinjauan literatur. Wellness and Healthy Magazine, 2(1), 187-192. https://doi.org/10.2307/j.ctvzxxb18.1 2 